\title{
Cell cycle phase perturbations and apoptosis in tumour cells induced by aplidine
}

\author{
E Erba*,', L Bassano', G Di Liberti', I Muradore', G Chiorino',5, P Ubezio', S Vignati', A Codegoni', \\ MA Desiderio ${ }^{2}$, G Faircloth ${ }^{3}, J^{J}$ Jimeno $^{4}$ and M D'Incalci'
}

\begin{abstract}
'Cancer Pharmacology Laboratory, Department of Oncology, Istituto di Ricerche Farmacologiche Mario Negri, via Eritrea 62, 20157 Milan, Italy; ${ }^{2}$ Institute of General Pathology and CNR Center for Research on Cell Pathology, University of Milan, via L Mangiagalli 31, 20133 Milan, Italy; ${ }^{3}$ PharmaMar USA, Inc., 320 Putnam Avenue, Cambridge, Massachusetts, MA 02139, USA; ${ }^{4}$ PharmaMar SA, Research and Development, Calle de la Calera 3, 28760 Tres Cantos, Madrid, Spain
\end{abstract}

Aplidine, dehydrodidemnin B, is a marine depsipeptide isolated from the Mediterranean tunicate Aplidium albicans currently in phase II clinical trial. In human Molt-4 leukaemia cells Aplidine was found to be cytotoxic at nanomolar concentrations and to induce both a $G_{1}$ arrest and a $G_{2}$ blockade. The drug-induced cell cycle perturbations and subsequent cell death do not appear to be related to macromolecular synthesis (protein, RNA, DNA) since the effects occur at concentrations (e.g. $10 \mathrm{nM}$ ) in which macromolecule synthesis was not markedly affected. Ten nM Aplidine for I h inhibited ornithine decarboxylase activity, with a subsequently strong decrease in putrescine levels. This finding has questionable relevance since addition of putrescine did not significantly reduce the cell cycle perturbations or the cytotoxicity of Aplidine. The cell cycle perturbations caused by Aplidine were also not due to an effect on the cyclin-dependent kinases. Although the mechanism of action of Aplidine is still unclear, the cell cycle phase perturbations and the rapid induction of apoptosis in Molt-4 cells appear to be due to a mechanism different from that of known anticancer drugs.

British Journal of Cancer (2002) 86, I5I0-1517. DOI: 10.1038/sj/bjc/6600265 www.bjcancer.com

(C) 2002 Cancer Research UK

Keywords: natural compound; Aplidine; cell cycle; apoptosis

Aplidine, dehydrodidemnin B (Figure 1, chemical structure), is a marine depsipeptide isolated from the Mediterranean tunicate Aplidium albicans, that is structurally related to didemnin $\mathrm{B}$, and has been shown to be in vitro active against both human haemathological and solid tumour cell lines (Urdiales et al, 1996; Lobo et al, 1997; Depenbrock et al, 1998; Geldof et al, 1999), Moreover, Aplidine has been shown to be active against in vivo murine B16 melanoma and in several human tumours growing in athymic mice (Faircloth et al, 1995, 1996).

It has been described that didemnins inhibit the progression from $G_{1}$ to $S$ phase of the cell cycle (Crampton et al, 1984). Several biochemical effects of didemnins have also been reported: inhibition of protein synthesis via GTP-dependent elongation factor 1alpha in vitro (Crews et al, 1994), and of protein, DNA and RNA syntheses in different cell lines (Crampton et al, 1984; Sakai et al, 1996) Inhibition of the ornithine decarboxylase (ODC) activity by didemnins was previously described (Urdiales et al, 1996), but the relevance of this biochemical effect for the antitumour activity of Aplidine has not been shown.

The present study purpose is to better characterise the mechanisms involved in the Aplidine-induced antiproliferative effect, cell

*Correspondence: E Erba, Head, Flow Cytometry Unit, Department of Oncology, Istituto di Ricerche Farmacologiche Mario Negri, Via Eritrea, 62, 20157 Milan, Italy; E-mail: erba@marionegri.it

${ }^{5}$ Current address: Fondo Edo Tempia, Via Malta, 3 - 13900 Biella, Italy Received 9 August 200 I; revised 13 February 2002; accepted 26 February 2002 cycle perturbations and cell death induced in human Molt-4 leukaemia cell line.

\section{MATERIALS AND METHODS}

\section{Drug treatment}

Aplidine (Figure 1) was generously provided by PharmaMar. The cytotoxic effect of Aplidine on Molt-4 cells was evaluated by exposing the cells for different times to the drug and by counting the number of cells at different time intervals after drug-washout by a Coulter Counter instrument.

\section{Cell cycle}

Monoparametric DNA analysis and cell flux simulation Exponentially growing Molt- 4 cells were treated for $1 \mathrm{~h}$ with 0,1 , 5, 10, 20 or $30 \mathrm{~nm}$ Aplidine. At 24, 48 and $72 \mathrm{~h}$ after drug-washout the number of cells was evaluated by counting the cells with a Coulter Counter instrument, and the cells were fixed in $70 \%$ ethanol and kept at $4{ }^{\circ} \mathrm{C}$ before DNA staining with propidium iodide. DNA flow cytometric analysis were performed on at least 10000 cells using a FACSCalibur system (Becton Dickinson, Sunnyvale, CA, USA). The coefficient of variation of the $\mathrm{G}_{1}$ peak of the Molt-4 fixed cells was between 2 and $2.5 \%$. The DNA histograms of each sample were analysed and the percentages of cells in each cell cycle phase were derived by means of a home-made fitting programme based on the sum-of-gaussians method (Ubezio, 1985; Sena et al, 1999). However the direct analysis of the experimental data expressed as percentage of cells in a given phase can be 
<smiles>CCC(C)[C@H](NC(=O)[C@H](NC(=O)C(CC(C)C)N(C)C(=O)C1CCCN1C(=O)C(C)=O)C(C)OC(=O)C(Cc1ccc(OC)cc1)N(C)C(=O)C1CCCN1C(=O)C(CC(C)C)NC(=O)[C@H](C)C(=O)C(OC(=O)CC(O)C(C)C)C(C)C)C(C)C</smiles>

Figure I Aplidine chemical structure

misleading if there is a concomitant cell cycle block with killing in one or different phases of the cell cycle. In fact if the drug kills in one phase and blocks in the same phase the percentage of cells in that phase might be similar to that of untreated control cells. This is explained by the fact that a cell killing effect results in a decrease of the percentage and the block is a relative increase in that percentage. The relative importance of the two effects, i.e. blocking and cell killing can vary overtime making the interpretation of the data virtually impossible. In addition when the block is overcome there might be a wave of synchronisation with changes in the relative distribution of cells in the different phases compared to asynchronous cell cycle distribution of control cells.

In order to overcome these interpretation problems we have developed and used a simulation programme, previously described in detail (Montalenti et al, 1998; Sena et al, 1999), based on the kinetic properties of the cell line.

The simulation programme forecasts the cell cycle flux in a cell population, starting from the cell cycle distribution at a given time hypothesising the probability that a cell is blocked or killed in a cell cycle phase. The time-course of cell counts and of $\% \mathrm{G}_{1}, \% \mathrm{~S}$ and $\% \mathrm{G}_{2} \mathrm{M}$ are given as output and can be compared with actual data.

Thus, the programme enables us to test a hypothesis on the time-course of blocking and killing that can occur in each phase to correlate with the data. The latest version of the programme runs on a personal computer using Microsoft Excel and is available from the author (ubezio@marionegri.it).

Biparametric BrdUrd/DNA analysis During the last $15 \mathrm{~min}$ of $1 \mathrm{~h}$ Aplidine exposure, $20 \mu \mathrm{M}$ bromodeoxyuridine (BrdUrd) was added to the cells. After treatment the cells were washed twice with PBS and fresh medium was provided. After $1 \mathrm{~h}$ treatment and at 4, $8,12,24,29,36$ and $48 \mathrm{~h}$ after drug-washout control and treated cells were fixed in $70 \%$ ethanol and kept at $4^{\circ} \mathrm{C}$ before BrdUrd/ DNA flow cytometric analysis (Erba et al, 2001). With this protocol it was also possible to obtain a distinct evaluation of cell cycle perturbations in cells which were in $S$ phase (BrdUrd positive cells) or in $G_{1}$ or in $G_{1} M$ phases (BrdUrd negative cells) during $1 \mathrm{~h}$ $10 \mathrm{~nm}$ Aplidine exposure.

\section{Ornithine decarboxylase (ODC) activity assay}

Frozen cells $\left(5 \times 10^{6}\right)$ were sonicated in $100 \mu$ l of cold Tris- $\mathrm{HCl}$ ( $\mathrm{pH}$ 7.2) containing $0.1 \mathrm{~mm}$ EDTA and $2 \mathrm{~mm}$ DTT and were subsequently centrifuged at 14000 r.p.m. for $20 \mathrm{~min}$ in an Eppendorf microcentrifuge at $4^{\circ} \mathrm{C}$. ODC activity was measured in the supernatants as release of labelled $\mathrm{CO}_{2}$ from $\left[1-{ }^{14} \mathrm{C}\right]$ ornithine (56 Ci mol ${ }^{-1}$, Amersham Pharmacia Biotech, Milan, Italy), as previously reported (Desiderio et al, 1993). The reaction mixture (final volume $250 \mu \mathrm{l}$ ) contained cytosol supernatant (about $150 \mu \mathrm{g}$ of protein), $50 \mathrm{~mm}$ Tris- $\mathrm{HCl}(\mathrm{pH} 7.1)$, and $1 \mathrm{~mm}$ $\left[1-{ }^{14} \mathrm{C}\right]$ ornithine (sp. act. $4 \mathrm{Ci} \mathrm{mol}^{-1}$ ). Blanks were prepared in the presence of $4 \mathrm{mM} \alpha$-difluoromethylornithine (generously given by Marion Merrell Dow Research Institute, Strasbourg, France) to inhibit ODC activity. ODC activity is reported as pmol of $\mathrm{CO}_{2}$ formed in $1 \mathrm{~h}$ per $\mathrm{mg}$ of protein. Protein content in cytosol extracts was assayed by the standard method (Lowry et al, 1951).

\section{Polyamine determination}

Frozen cell samples $\left(3 \times 10^{6}\right)$ were sonicated in $80 \mu \mathrm{l}$ of $0.2 \mathrm{~N} \mathrm{PCA}$ and then centrifuged at 5000 r.p.m. in an Eppendorf microcentrifuge for $20 \mathrm{~min}$. Aliquots of supernatants were analysed by HPLC (Perkin-Elmer Corp., Norwalk, CN, USA) using a $\mathrm{C}_{18}$ reverse-phase column ( $4 \mu \mathrm{m}$ particle size, $150 \times 3.9 \mathrm{~mm}$, Waters). Evaluation of polyamines was performed after post-column derivatisation with $o$-phtaldialdehyde and fluorescence detection (Desiderio, 1992).

\section{DNA, RNA and proteins synthesis assay}

Exponentially growing cells were treated with different concentrations of Aplidine. At different drug exposure time intervals $1 \mu \mathrm{Ci} \mathrm{ml}{ }^{-1}\left[{ }^{3} \mathrm{H}\right]$ thymidine, or $1 \mu \mathrm{Ci} \mathrm{ml}{ }^{-1}\left[{ }^{3} \mathrm{H}\right]$ uridine, or $2 \mu \mathrm{Ci} \mathrm{ml}{ }^{-1}\left[{ }^{3} \mathrm{H}\right]$ leucine were added to the cells for $2 \mathrm{~h}$ and the radioactivity was evaluated by using a liquid scintillator counter.

\section{Extracts preparation, Western blotting analysis and CDK activity}

Cell extracts were prepared by addition of lysis buffer containing protease inhibitors according to standard procedures (Sambrook et al, 1989). Extracts corresponding to $100 \mathrm{mg}$ of protein were separated on $12 \%$ SDS-PAGE, blotted onto nitrocellulose membranes, and incubated with antibodies against cyclins B, D1 and E, Cdk2, Cdk4, Cdc2, p21, p16, p53, pRb, Bax and Caspase 3 (Santa Cruz Biotech.,Inc., Heidelberg, Germany). As secondary antibodies, horseradish peroxidase labelled anti-rabbit or antimouse antibodies (Santa Cruz Biotech) were used. Protein bands were visualised by enhanced chemiluminescence. Kinase activity was measured as previously reported (Bonfanti et al, 1997)

\section{Detection of apoptotic process}

The fraction of apoptotic cells after Aplidine exposure was evaluated by Terminal-dUTP-Transferase (TdT) flow cytometric assay as previously described (Bergamaschi et al, 1999).

\section{RESULTS}

\section{Growth inhibition}

Aplidine was active at nanomolar concentrations, which induced a dose-dependent growth inhibition in Molt-4 cells (Figure 2) and the effects appeared to be similar at $1 \mathrm{~h}$ (A) and $24 \mathrm{~h}$ treatment time (B).

\section{Cell cycle studies}

We were interested in evaluating the drug's effects on $G_{1}, S$ and $\mathrm{G}_{2} \mathrm{M}$ phases separately to distinguish blocking or delaying effects from killing ones. Figure 3 shows the experimental percentages of $\mathrm{G}_{1}$ and $\mathrm{G}_{2} \mathrm{M}$ at different times after Aplidine treatment, compared to the amount of blocked or lost cells resulting from the simulation. The computer simulation allowed us to discard any data not including all the effects of block and killing in each phase reported below. The chosen simulation reproduces experi- 
A

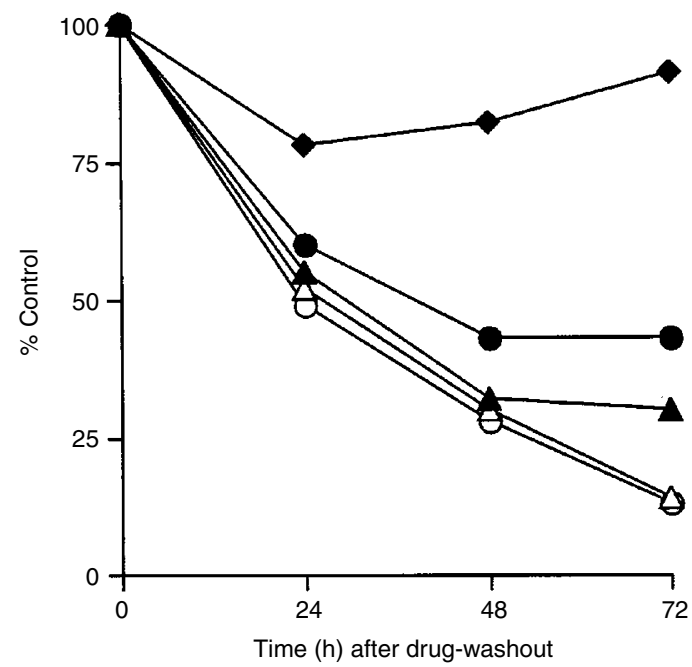

B

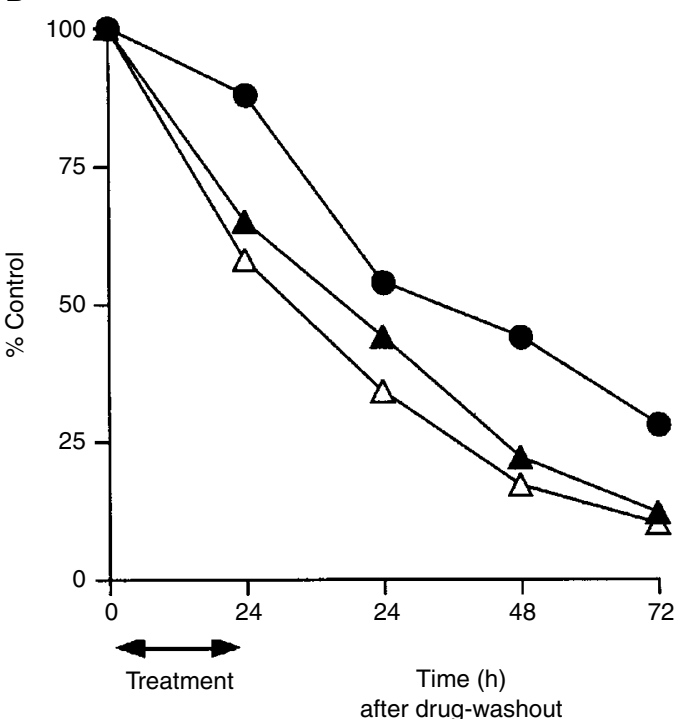

Figure 2 Effect of I h (A) or 24 h (B) Aplidine exposure on cell growth evaluated at different time intervals after treatment and drug-washout. Each point is the mean of three replicates; bars represent the standard deviation. Solid diamond=Aplidine I nM; solid circle=Aplidine $5 \mathrm{nM}$; solid triangle= Aplidine 10 nM; open triangle=Aplidine 20 nM; open circle=Aplidine 30 nM.

mental cell cycle percentages within $2 \%$ and experimental cell counts within $10 \%$. Notice that the method allows us to estimate the percentage of cells blocked in $G_{1}$ and $G_{2} M$ and the number of dead cells, distinguishing between cells that have died when they were blocked in $G_{1}$ or in $G_{2} M$.

As shown in Figure 3A, the simulation required the introduction of a partial $\mathrm{G}_{2} \mathrm{M}$ block to reproduce the experimental data at concentrations as low as $5 \mathrm{nM}$. Among the cells exiting from $\mathrm{G}_{2} \mathrm{M}$ between 0 and $6 \mathrm{~h}(2.6 \%$ of the whole cell population per hour in controls), the probability of being blocked ranged from $15 \%(5 \mathrm{nM})$ to $22 \%(30 \mathrm{nM})$ resulting in the $2.3-3.2 \%$ cells in the $\mathrm{G}_{2} \mathrm{M}$ block at $6 \mathrm{~h}$. According to the simulation, after $48 \mathrm{~h}$ drug-washout, $\mathrm{G}_{2} \mathrm{M}$ blocked cells were not detectable $(<1 \%)$ using $\leqslant 10 \mathrm{~nm}$ Aplidine, due to either their death or exit from the block, while at higher concentration blocked cells were detected up to $72 \mathrm{~h}$ despite a continuous loss (Figure $3 \mathrm{~A}, \mathrm{~B}$ ). Mortality in $\mathrm{G}_{2} \mathrm{M}$ peaked around $24 \mathrm{~h}$ with any Aplidine concentration from 5 to $30 \mathrm{nM}$.
A

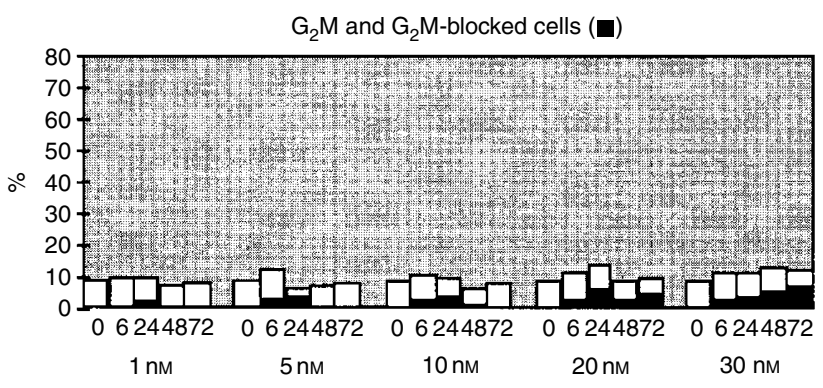

B

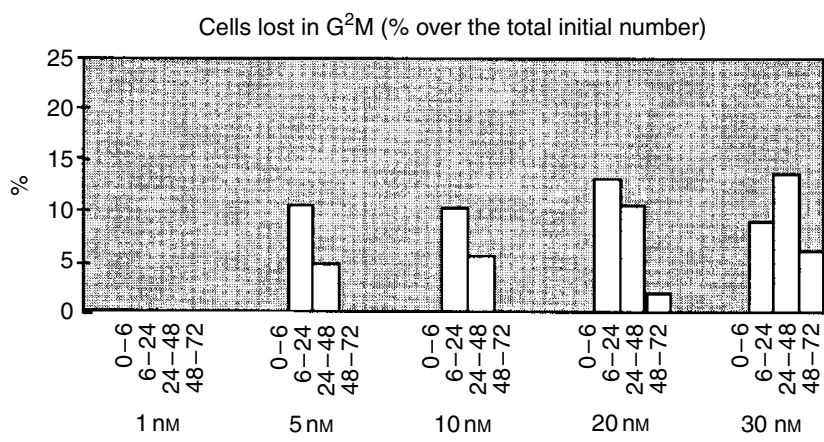

C

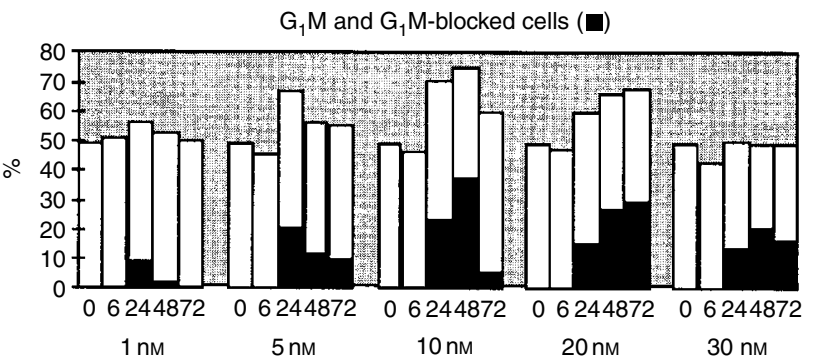

D

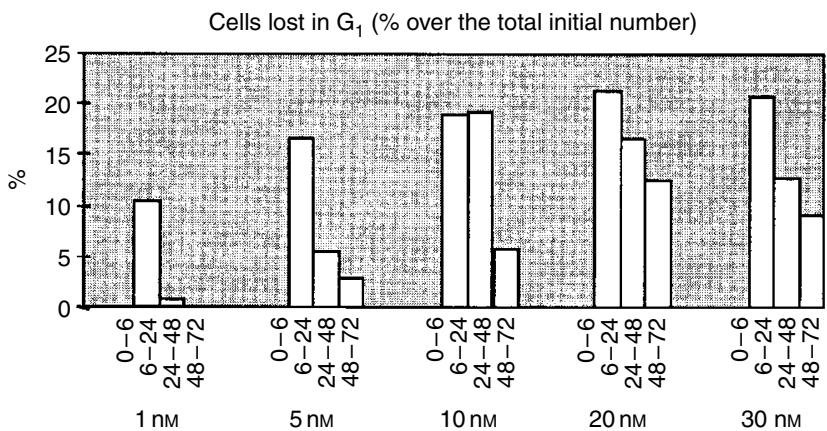

Figure 3 (A-C) Percentages of cells in $\mathrm{G}_{2} \mathrm{M}(\mathbf{A})$ and $\mathrm{G}_{1}(\mathbf{C})$ cell cycle phases. The black columns indicate the percentage of blocked cells in $\mathrm{G}_{2} \mathrm{M}$ or $G_{1}$, as resulting from simulation of experimental cell cycle percentages and absolute cell counts. (B - D) Percentage of cell cohort, from the overall initial population, which have died during $G_{2} M(B)$ or $G_{1}$ (D) block and evaluated at different time intervals after drug-washout (simulation results).

A $\mathrm{G}_{1}$ block was suggested by the simulation, at any concentration starting from $24 \mathrm{~h}$ after drug-washout, even when the observed per cent $G_{1}$ was not increasing over time after treatment with $30 \mathrm{~nm}$ Aplidine (Figure 3C,D). The percentage of $\mathrm{G}_{1}$ blocked cells after treatment with the concentrations higher than $10 \mathrm{nM}$ increased from 24 to $48 \mathrm{~h}$, indicating that even those cells that entered $G_{1}$ between 24 and $48 \mathrm{~h}$ were susceptible to arrest. A 
long-lasting continuous $\mathrm{G}_{1}$ block, with 20 and $30 \mathrm{nM}$ Aplidine, was suggested by the presence of $G_{1}$ blocked cells at 72 h despite their loss. A different balance between arrest and death resulted in a different behaviour with lower concentrations: more blocked cells

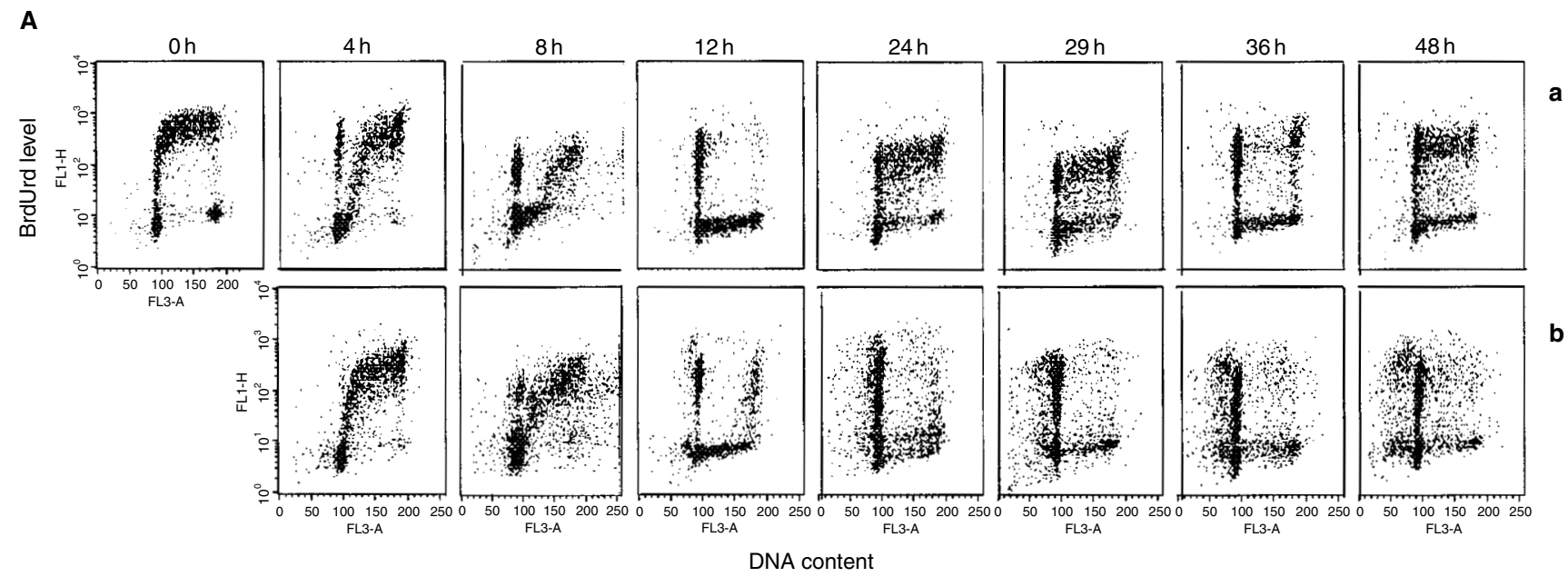

B

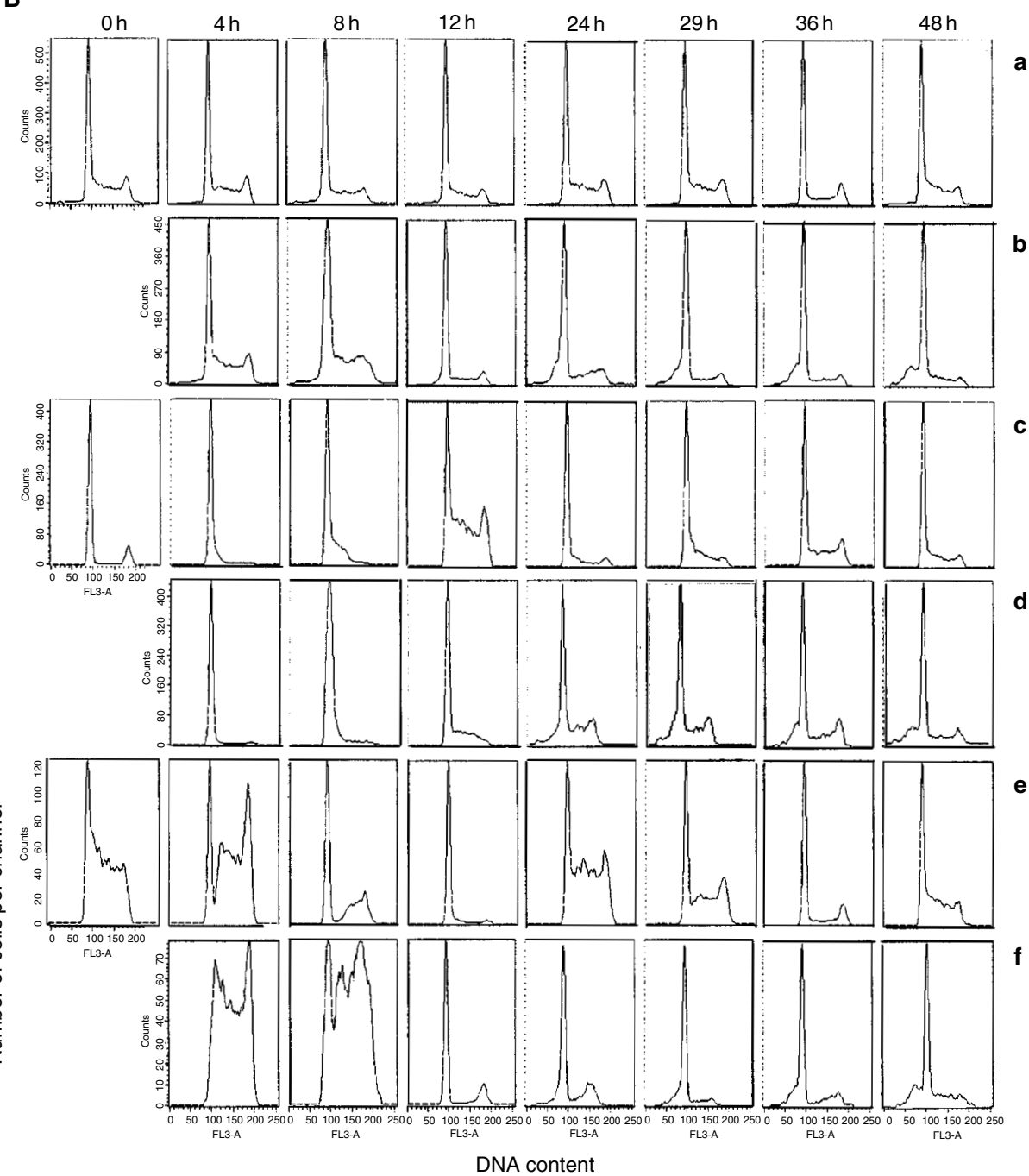

Figure 4 Effects of I h Aplidine exposure on the cell cycle phase distribution of Molt-4 cells evaluated at 0, 4, 8, 12, 24, 29, 36 and $48 \mathrm{~h}$ after drugwashout. During the last 15 min 10 nM Aplidine treatment, $20 \mu \mathrm{M}$ BrdUrd was added to the cells, then the cells were washed with PBS and drug-free medium was provided. (A) Biparametric BrdUrd/DNA analysis of (a) control cells; and (b) Aplidine treated cells. (B) DNA histograms of (a) control cells (whole population); (b) Aplidine treated cells (whole population); (c) BrdUrd-negative control cells; (d) BrdUrd-negative Aplidine treated cells; (e) BrdUrdpositive control cells; and (f) BrdUrd-positive Aplidine treated cells. The data are representative of three independent replicates. 
were obtained with $5(9 \%)$ than with $10 \mathrm{~nm}(5 \%)$ at $72 \mathrm{~h}$, due to the higher mortality with $10 \mathrm{~nm}$. Although more cells died in $\mathrm{G}_{1}$ than in $G_{2} M, G_{1}$ lost cells were proportionally less than $G_{2} M$ lost cells after correction for the amount of cells present in these phases. For instance, with $20 \mathrm{nM}$, the number of cells that globally (in the $0-72 \mathrm{~h}$ interval) died in $\mathrm{G}_{1}$ was double than in $\mathrm{G}_{2} \mathrm{M}$, but per cent $G_{1}$ was on average four-fold per cent $G_{2} M$ and $29 \%$ cells were blocked in $\mathrm{G}_{1}$ against $4 \%$ in $\mathrm{G}_{2} \mathrm{M}$ at $72 \mathrm{~h}$.

A temporary $S$ phase delay was observed with intermediate doses; this effect became strong and persistent only at $30 \mathrm{nM}$ Aplidine. No mortality effect was detected in S phase (data not shown).

Figure 4 shows the effects on the cell cycle phase distributions caused by $1 \mathrm{~h}$ exposure with $10 \mathrm{~nm}$ Aplidine in Molt- 4 cells evaluated by BrdUrd/DNA flow cytometric analysis at different time intervals after drug-washout. After Aplidine-washout, cells which were in the $S$ phase (BrdUrd positive cells) during drug treatment, progressed through this phase of the cell cycle more slowly than control cells. At $8 \mathrm{~h}$ the fraction of cells that started a new cell cycle $\left(\mathrm{G}_{1}\right.$ BrdUrd positive cell population) was higher in control $(27 \%)$ rather than Aplidine treated cells (8\%). At $24 \mathrm{~h}$ and up to $48 \mathrm{~h}$ after drug-washout the data are indicative of a $G_{1}$ block, in agreement with simulation studies.

Aplidine was found to delay those cells that were in the $G_{1}$ phase (BrdUrd negative cells) during drug treatment, from entering $\mathrm{S}$ phase. At 24 and up $48 \mathrm{~h}$ after Aplidine-washout the majority of the BrdUrd negative cells were blocked in the $G_{1}$ phase too.

\section{ODC activity}

As shown in Figure 5A, $1 \mathrm{~h}$ exposure to 10 or $20 \mathrm{~nm}$ Aplidine caused an inhibition of ODC of $75 \%$. The same percentage of inhi- bition was observed after $24 \mathrm{~h}$ of exposure. Aplidine per se did not affect ODC activity of a partially purified preparation, obtained by centrifugation of the cell homogenate at 14000 r.p.m. for $20 \mathrm{~min}$ in an Eppendorf microcentrifuge at $20^{\circ} \mathrm{C}$. This was shown by adding directly the drug ( $20 \mathrm{~nm}$ Aplidine) to test tubes containing all the components for ODC activity assay including the supernatant (about $150 \mu \mathrm{g}$ of protein) (data not shown). At $24 \mathrm{~h}$ after drug-washout we observed a persistent inhibitory effect of the Aplidine on ODC activity. However, control ODC activity was stimulated by the addition of fresh medium $(24+24)$.

In agreement with the decrease of ODC activity, we observed that putrescine levels diminished in Aplidine treated cells at $1 \mathrm{~h}$ (30 and $60 \%$ for Aplidine 10 and $20 \mathrm{nM}$ respectively) and at $24 \mathrm{~h}(80 \%$ decrease) at both concentrations (Figure 5B). At $24 \mathrm{~h}$ after drug-washout ( 1 or $24 \mathrm{~h}$ treatment plus $24 \mathrm{~h}$ drug-washout) putrescine levels further decrease in Aplidine treated cells, while the control cells showed a huge increase probably due to fresh medium change that increased also ODC activity. Only spermidine level decreased $(60-80 \%)$ at $24 \mathrm{~h}$ after drug-washout in $24 \mathrm{~h}$ Aplidine treated cells. At the other times of treatment higher polyamine (spermidine and spermine) levels were unaffected by Aplidine (Figure 5B).

To evaluate if decreased levels of putrescine could be important for the cytotoxic effect of Aplidine, $1 \mathrm{~mm}$ putrescine was added to the cells $2 \mathrm{~h}$ before $1 \mathrm{~h}$ Aplidine treatment. Then the drug-containing medium was removed and fresh medium containing $1 \mathrm{~mm}$ putrescine was added to the cells. Under these conditions the intracellular levels of putrescine were $6.44 \mathrm{nmol} \mathrm{mg}{ }^{-1}$ protein in control cells, $16.8 \mathrm{nmol} \mathrm{mg}^{-1}$ protein putrescine pretreated control cells, $4.7 \mathrm{nmol} \mathrm{mg}{ }^{-1}$ protein Aplidine treated cells and $16.9 \mathrm{nmol} \mathrm{mg}{ }^{-1}$ protein in Aplidine treated cells preincubated

A

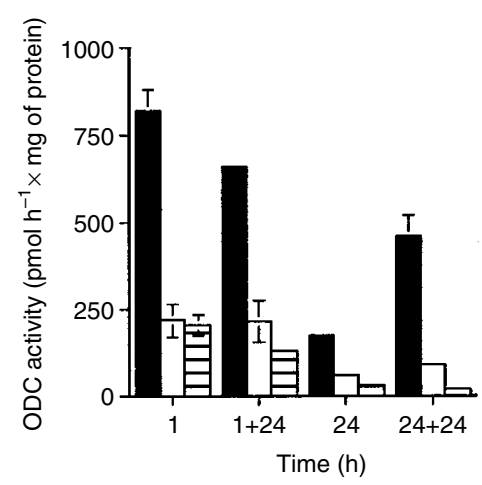

B
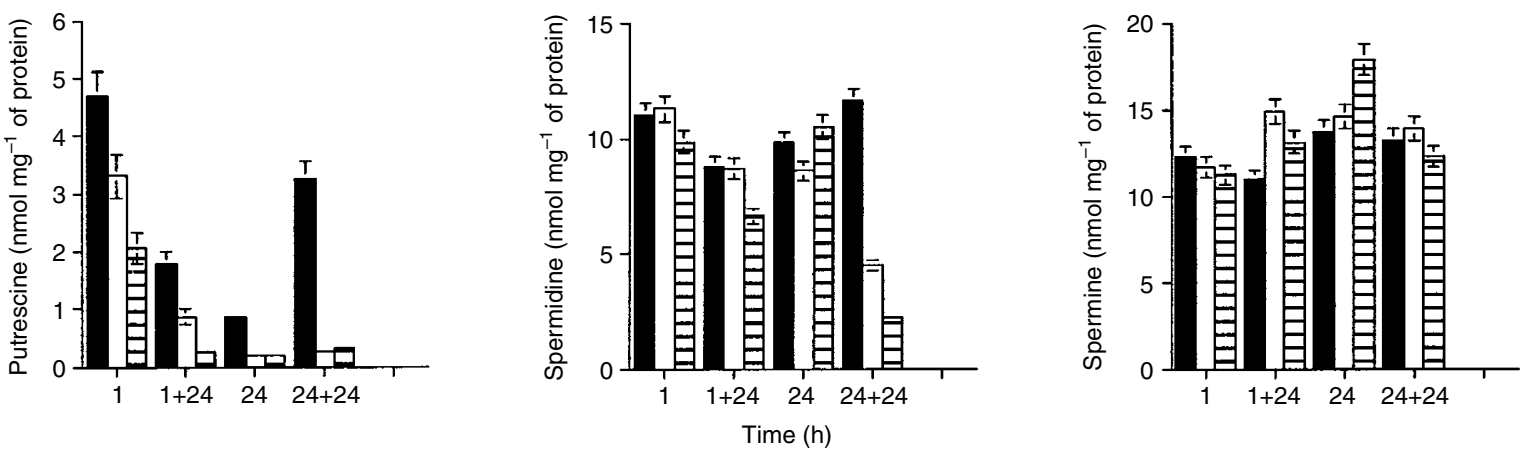

Figure 5 (A) Ornithine decarboxylase (ODC) activity evaluated after I and $24 \mathrm{~h}$ Aplidine treatment and at $24 \mathrm{~h}$ after drug-washout. The data are the mean \pm s.e. of three independent experiments performed in duplicate. $|=| \mathrm{h}$ Aplidine treatment; $|+24=| \mathrm{h}$ Aplidine treatment $+24 \mathrm{~h}$ drug-washout; $24+24=24 \mathrm{~h}$ Aplidine treatment $+24 \mathrm{~h}$ drug-washout; solid square=control cells; open square $=10 \mathrm{nM}$ Aplidine; striped square=20 nM Aplidine. (B) Putrescine, spermidine and spermine determinations performed after I and $24 \mathrm{~h}$ Aplidine treatment and at $24 \mathrm{~h}$ after drug-washout. The data are the mean \pm s.e. of three independent experiments performed in duplicate. I $=1 \mathrm{~h}$ treatment; $I+24=1 \mathrm{~h}$ treatment plus $24 \mathrm{~h}$ drug-washout; $24=24 \mathrm{~h}$ treatment; $24+24=24 \mathrm{~h}$ treatment plus $24 \mathrm{~h}$ drug-washout; solid square $=$ control cells; open square $=10 \mathrm{nM}$ Aplidine; striped square $=20 \mathrm{nM}$ Aplidine. 
with $1 \mathrm{~mm}$ putrescine. In spite of the fact that intracellular putrescine levels were comparable to that of control cells Aplidine was equally cytotoxic indicating that the cytotoxicity was not related to putrescine depletion (data not shown).

\section{Macromolecular synthesis}

DNA, RNA and protein synthesis were evaluated after 1, 4, 8 and $24 \mathrm{~h}$ Aplidine exposure in Molt-4 cells. One hour Aplidine treatment at concentrations up to $50 \mathrm{~nm}$ did not cause a significant inhibition of DNA, RNA or protein synthesis. Inhibition of DNA, RNA and protein synthesis were obtained only at higher Aplidine concentrations (i.e. after $1 \mathrm{~h}$ with concentrations $>100 \mathrm{nM}$ ) and/or a time exposures (i.e. after $8 \mathrm{~h}$ with concentrations $\geqslant 50 \mathrm{nM}$; data not shown).

\section{Cell cycle related proteins}

We then evaluated the expression of proteins that regulate cellcycle progression at the end of treatment with $10 \mathrm{~nm}$ Aplidine and 4,8 and $24 \mathrm{~h}$ after drug-washout by Western blot analysis. As shown in Figure 6A, the protein levels of Cdk2, Cdc2 and Cdk4, cyclin B and D1 remained constant at each time tested, with only a decline in cyclin E levels observable at $24 \mathrm{~h}$ after drug-washout. p16 levels were undetectable in Molt-4 lysates in agreement with the previously reported deletion of this gene in this cell line (Uchida et al, 1995).

The levels of p21, p53 and pRb, did not change under these experimental conditions.

Cdk2 Kinase activity measured at the end of $1 \mathrm{~h}$ treatment with $10 \mathrm{~nm}$ Aplidine (time $0 \mathrm{~h}$ ) and at 4 and $24 \mathrm{~h}$ after drug-washout was not affected by drug treatment (Figure 6B). Cdk2 and cyclin E protein levels did not change in Western blot analysis of immunoprecipitates.

Similarly, Aplidine did not inhibit Cdk2 activity in vitro using recombinant Cdk2/cyclinE and Cdk2/cyclinA complexes (data not shown)

\section{Cell death}

We investigated the mechanism of cell death induced by Aplidine by using TdT-dUTP flow cytometric analysis. One hour Aplidine exposure already induced apoptosis in Molt- 4 cells at $6 \mathrm{~h}$ after drug-washout, and the fraction of apoptotic cells was dose and time dependent (Figure 7). By using biparametric DNA/TdTdUTP flow cytometric analysis we did not observe a specific cell cycle phase dependency of the apoptotic cell death (data not shown).

To evaluate if caspase 3 was involved in the induction of apoptosis we performed Western blotting analysis on the total protein extract of Molt- 4 cells treated for 1 h with 10 or 20 nM with Aplidine. The analysis was performed after drug treatment and at 6 and $24 \mathrm{~h}$ after drug-washout. As shown in Figure 8 we found that in the $10 \mathrm{nM}$ treated cells just after $1 \mathrm{~h}$ treatment caspase 3 was cleaved into its $12 \mathrm{kDa}$ activated form. At 6 and $24 \mathrm{~h}$ after drugwashout the activation of caspase 3 with the appearance of 12 and $20 \mathrm{kDa}$ activated forms was clearly evident. Bax levels were not changed after treatment indicating that the apoptotic pathway was bax independent.

\section{DISCUSSION}

The present study shows that Aplidine causes profound perturbations of the cell cycle as well as apoptosis in the human lymphoblastic leukaemia cell line Molt-4 at very low concentrations (nM range).

The concentrations $(20 \mathrm{nM})$ which produced significant cell death can be achieved for several hours in the plasma of patients
A

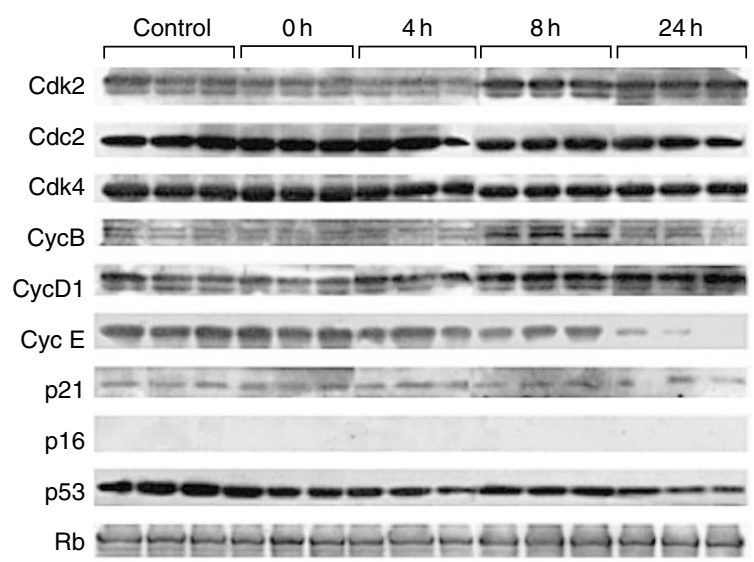

B
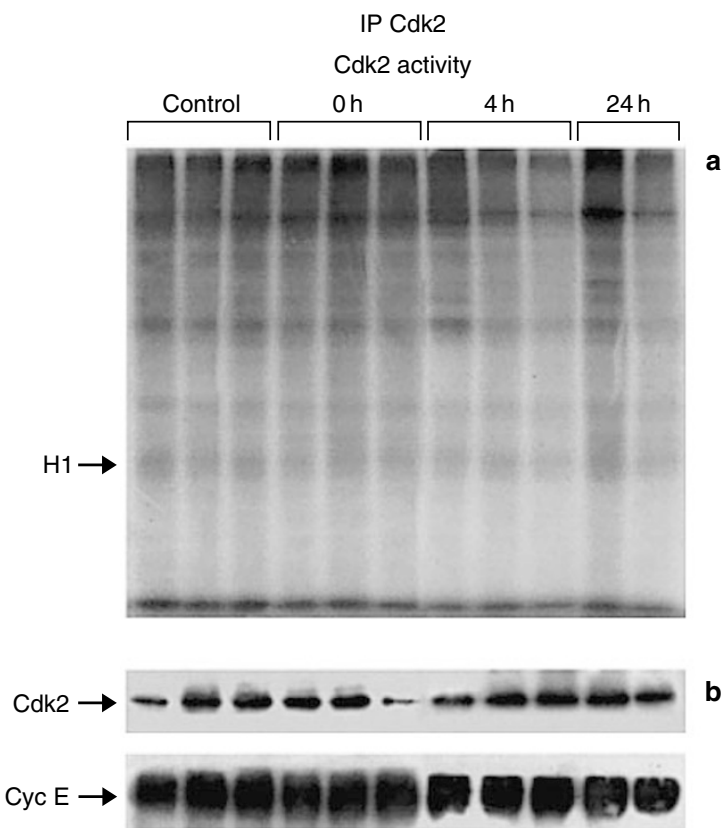

Figure 6 (A) Immunoblot analysis of Cdk2, Cdc2, Cdk4, cyclin BI, DI and $\mathrm{E}, \mathrm{p} 2 \mathrm{I}, \mathrm{p}$ |6, p53, and pRb expression in Molt-4 cells treated for I h with 10 nM Aplidine (three independent replicates). Molt-4 extracts were collected before and after treatment and, at 4, 8, $24 \mathrm{~h}$ after drug washout. One hundred $\mu$ g of protein extracted from cells were immunoblotted with specific antibodies as described in Materials and methods. (B) (a) Histone $\mathrm{HI}$ phosphorylation in Molt-4 cells lysates immunoprecipitated with Cdk2 antibodies. Cells were exposed for I h to $10 \mathrm{nM}$ Aplidine $(0 \mathrm{~h})$ and then incubated in drug free medium ( 4 and $24 \mathrm{~h}$ after drug-washout) (three independent replicates). (b) Western blot analysis of C dk2 and cyclin E in Cdk2 immunoprecipitates (three independent replicates).

receiving Aplidine doses ranging from 3750 to $6000 \mu \mathrm{g} \mathrm{m}^{-2}$ given as a $24 \mathrm{~h}$ infusion (Paz-Ares et al, 2000; Armand et al, 2001).

A new finding, reported here for the first time is that Aplidine not only induces a $\mathrm{G}_{1}$ arrest (Crampton et al, 1984), but also a $\mathrm{G}_{2}$ blockade. It is interesting to note that the block in $\mathrm{G}_{2}$ is probably relevant as a large proportion of cells blocked in this phase subsequently undergo cell death. Whatever the mechanism of action of Aplidine, it acts very quickly and a prolonged exposure time (e.g. from $15 \mathrm{~min}$ to 1 or $24 \mathrm{~h}$ ) does not increase the effects of the drug proportionally. 

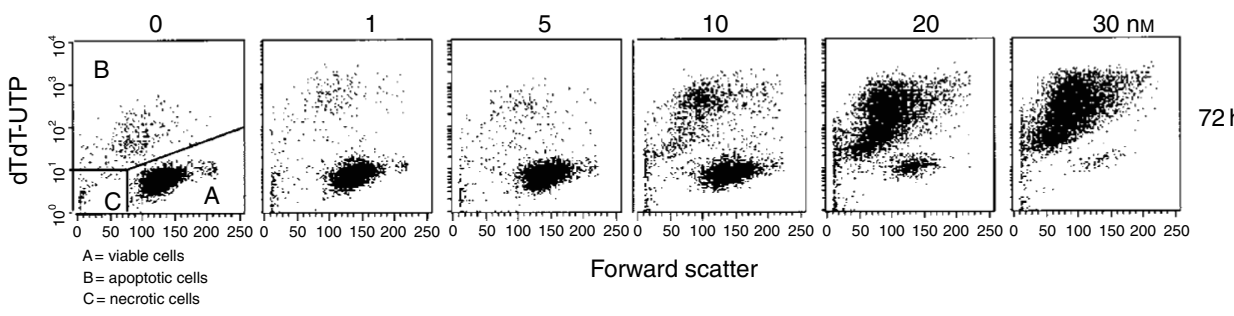

Forward scatter

\begin{tabular}{llllllll}
\multicolumn{8}{c}{ \% of apoptotic cells } \\
\hline Time (h) & 0 & 1 & 5 & 10 & 20 & $30 \quad$ (Aplidine nM) \\
\hline 6 & 4 & 4 & 4 & 9 & 13 & 18 \\
24 & 4 & 4 & 5.5 & 20 & 49 & 69 \\
48 & 5 & 5 & 5 & 22 & 72 & 88 \\
72 & 5 & 5 & 4.5 & 26 & 87 & 95
\end{tabular}

Figure 7 Detection of apoptosis. Cells were treated with different concentrations of Aplidine and the biparametric FSC/TdT-dUTP flow cytometric analysis were performed after 6, 24, 48 and $72 \mathrm{~h}$ after drug-washout. The percentage of apoptotic cells obtained at different time intervals and the flow cytometric FSC/TdT-dUTP analysis performed at $72 \mathrm{~h}$ after drug-washout are reported.

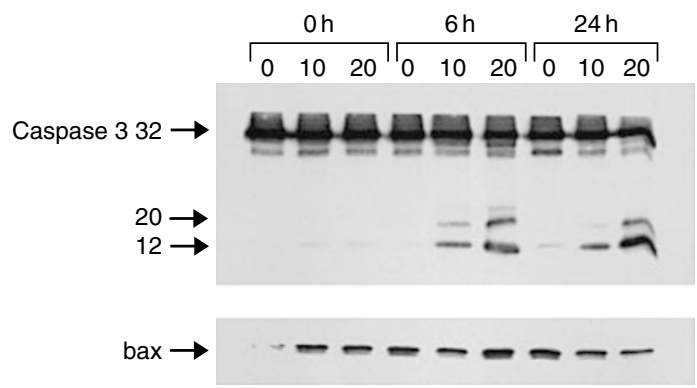

Figure 8 Western blot analysis of caspase 3 and Bax in Molt-4 cells treated for I h with 0, 10 or 20 nM Aplidine and evaluated at different time intervals after drug-washout.

It has been proposed that Aplidine acts by inhibiting protein synthesis as suggested by the fact that the structural analogue didemnim inhibits the $1 \alpha$-elongation factor (Crews et al, 1994). Our data do not support the contention that protein synthesis is the primary mechanism by which Aplidine is cytotoxic. In fact, there are clear perturbations of the cell cycle at drug concentrations and time intervals in which no major decrease in the total synthesis of proteins or of other macromolecules occurs. For example, a concentration of $10 \mathrm{nM}$ Aplidine for $1 \mathrm{~h}$ caused no detectable inhibition of total proteins, RNA or DNA synthesis but did cause marked cell cycle perturbations and cytotoxicity.

Another hypothesised mechanism of action of Aplidine was the inhibition of ODC (Urdiales et al, 1996). Intracellular polyamines, spermidine and spermine and their precursor putrescine are intimately involved in cell growth and proliferation. Intracellular polyamine levels are highly regulated and are primarily dependent upon the activity of ODC, that catalyses the first and rate-limiting step in polyamine biosynthesis. It has also been proposed that there exists polyamine-dependent restriction points during $G_{0}-G_{1}$ transition and $G_{1}$ phase progression of the cell cycle (Harada and Morris, 1981; Seidenfeld et al, 1986; Charollais and Mester, 1988). The present study confirms that in cells treated with Aplidine there is a marked inhibition of ODC activity, an effect that could not be reproduced in vitro on the partially purified enzyme.
The inhibition of ODC caused a strong decrease in putrescine levels which might be a relevant event triggering cell cycle perturbations and apoptosis. However, our data tend to exclude that depletion of putrescines plays a major role in the biological effects of Aplidine. In fact, the addition of putrescine at concentrations that increased intracellular putrescine concentrations comparable or even higher than that of controls did not significantly reduce cell cycle perturbations or the cytotoxicity of Aplidine.

Although further studies are required on this point it appears that the cell cycle perturbations observed after Aplidine treatment are not due to an effect on the cyclin dependent kinases that regulate the cell cycle progression. It appears more likely that the cell cycle block in $G_{1}$ or in $G_{2}$ is related to activation of cell cycle check points.

No information on the mechanism of cell cycle arrest is available but we can exclude the possibility that p53 is involved as Molt-4 cells do not express wt p53.

In addition, similar results have been obtained in other acute lymphoblastic leukaemia (ALL) lines with mutated p53 such as K562 and on fresh ALL cells grown on stromal feeder layer (Erba et al, in preparation).

In conclusion, although the data reported do not provide an explanation for the biological effects of Aplidine they indicate that this peptide acts by a mechanism different from that of other known anticancer drugs. The rapid induction of apoptosis in human leukaemia cells at concentrations even lower than those that can be achieved and maintained for many hours in plasma of patients receiving the drug at tolerable dose, provides a rational to undertake clinical investigation wit this drug in human leukaemia.

\section{ACKNOWLEDGEMENTS}

This work was partially supported by the projects No. ICS120/ RF98/73 and No. ICS0301/RF00/192 of the Italian Ministry of Health and by the CNR 'Progetto Strategico MURST - Legge 449/97 'Oncologia': Ricerca ed Applicazioni' No. 00.00028.ST97. The generous contribution of the Nerina and Mario Mattioli Foundation is gratefully acknowledged. 


\section{REFERENCES}

Armand JP, Ady-Vago N, Faivre S, Chieze S, Baudin E, Ribrag V, Lecot F, Iglesias L, Lopez-Lazaro L, Guzman C, Jimeno J, Ducreux M, Le Chevalier T, Raymond E (2001) Phase I and pharmacokinetic study of aplidine (APL) given as a 24-hour continuous infusion every other week ( $\mathrm{q} 2 \mathrm{w})$ in patients (pts) with solid tumor (ST) and lymphoma (NHL)[abstract]. Proc Am Soc Clin Oncol, Vol 20, 120a. Proceedings 37th ASCO Annual Meeting, May $12-15$, San Francisco

Bergamaschi D, Ronzoni S, Taverna S, Faretta M, De Feudis P, Faircloth G, Jimeno J, Erba E, D’Incalci M (1999) Cell cycle perturbations and apoptosis induced by isohomohalichondrin B (IHB), a natural marine compound. Br J Cancer 79: $267-277$

Bonfanti M, Taverna S, Salmona M, D'Incalci M, Broggini M (1997) p21WAF1-derived peptides linked to an internalization peptide inhibit human cancer cell growth. Cancer Res 57: 1442-1446

Charollais RH, Mester J (1988) Resumption of cell cycle in BALB/c-3T3 fibroblasts arrested by polyamine depletion: relation with competence gene expression. J Cell Physiol 137: 559-564

Crampton SL, Adams EG, Kuentzel SL, Li LH, Badiner G, Bhuyan BK (1984) Biochemical and cellular effects of didemnins A and B. Cancer Res 44: $1796-1801$

Crews CM, Collins JL, Lane WS, Snapper ML, Schreiber SL (1994) GTPdependent binding of the antiproliferative agent didemnin to elongation factor lalpha. J Biol Chem 269: 15411-15414

Depenbrock H, Peter R, Faircloth GT, Manzanares I, Jimeno J, Hanauske AR (1998) In vitro activity of aplidine, a new marine-derived anti-cancer compound, on freshly explanted clonogenic human tumour cells and haematopoietic precursor cells. Br J Cancer 78: 739-744

Desiderio MA (1992) Opposite responses of nuclear spermidine N8-acetyltransferase and histone acetyltransferase activities to regenerative stimuli in rat liver. Hepatology 15: $928-933$

Desiderio MA, Mattei S, Biondi G, Colombo MP (1993) Cytosolic and nuclear spermidine acetyltransferases in growing NIH 3T3 fibroblasts stimulated with serum or polyamines: relationship to polyamine-biosynthetic decarboxylases and histone acetyltransferase. Biochem J 293: 475-479

Erba E, Bergamaschi D, Bassano L, Damia G, Ronzoni S, Faircloth GT, D'Incalci M (2001) Ecteinascidin-743 (ET-743), a natural marine compound, with a unique mechanism of action. Eur J Cancer 37: 97-105

Faircloth G, Perez J, Fernandez JLSP, Avila J, Garcia M, Erba E, D’Incalci M, Canedo A, Garcia de Quesada T, Jimeno J (1995) Marine depsipeptides with activity against solid tumour models [abstract]. p 529. Proceedings 8th ECCO Congress, Paris, 29 October-2 November

Faircloth JG, Rinehart K, Nunez de Castro I, Jimeno J (1996) Dehydrodidemnin $B$ a new marine derived antitumour agent with activity against experimental tumour models. Ann Oncol 7: 34
Geldof AA, Mastbergen SC, Henrar RE, Faircloth GT (1999) Cytotoxicity and neurocytotoxicity of new marine anticancer agents evaluated using in vitro assays. Cancer Chemother Pharmacol 44: 312-318

Harada JJ, Morris DR (1981) Cell cycle parameters of Chinese hamster ovary cells during exponential, polyamine-limited growth. Mol Cell Biol 1: 594599

Lobo C, Garcia-Pozo SG, De Castro IN, Alonso FJ (1997) Effect of dehydrodidemnin B on human colon carcinoma cell lines. Anticancer Res 17: 333 336

Lowry OH, Rosenbrough NJ, Farr AL, Randall RJ (1951) Protein measurement with folin phenol reagent. J Biol Chem 193: 265-275

Montalenti F, Sena G, Cappella P, Ubezio P (1998) Simulating cancer-cell kinetics after drug treatment: application to cisplatin on ovarian carcinoma. Phys Rev E 57: 5877-5887

Paz-Ares L, Anthony A, Pronk L, Twelves C, Alonso S, Cortes-Funes H, Celli N, Gomez C, Lopez-Lazaro L, Guzman C, Jimeno J, Kaye S (2000) p 86. Proceedings 11th NCI-EORTC-AACR Symposium, November 7-10, Amsterdam

Sakai R, Rinehart KL, Kishore V, Kundu B, Faircloth G, Gloer JB, Carney JR, Namikoshi M, Sun F, Hughes Jr RG, Gravalos DG, De Quesada TG, Wilson GR, Heid RM (1996) Structure-activity relationships of the didemnins. J Med Chem 39: 2819-2834

Sambrook J, Fritsch EF, Maniatis T (1989) Molecular Cloning: A Laboratory Manual, Cold Spring Harbor, NY: Cold Spring Harbor Laboratory Press

Seidenfeld J, Block AL, Komar KA, Naujokas MF (1986) Altered cell cycle phase distributions in cultured human carcinoma cells partially depleted of polyamines by treatment with difluoromethylornithine. Cancer Res 46: $47-53$

Sena G, Onado C, Cappella P, Montalenti F, Ubezio P (1999) Measuring the complexity of cell cycle arrest and killing of drugs: kinetics of phase-specific effects induced by taxol. Cytometry 37: 113-124

Ubezio P (1985) Microcomputer experience in analysis of flow cytometric DNA distributions. Comput Programs Biomed 19: 159-166

Uchida T, Watanabe T, Kinoshita T, Murate T, Saito H, Hotta T (1995) Mutational analysis of the CDKN2 (MTS1/p16ink4A) gene in primary B-cell lymphomas. Blood 86: 2724-2731

Urdiales JL, Morata P, Nunez de Castro I, Sanchez-Jimenez F (1996) Antiproliferative effect of dehydrodidemnin B (DDB), a depsipeptide isolated from Mediterranean tunicates. Cancer Lett 102: 31-37 